\title{
School-Related Gender Based Violence (SRGBV) and Its Consequences on Secondary School Students: Implications for Counselling
}

\author{
Anna Onoyase \\ Correspondence: Assoc. Prof. Anna Onoyase, Department of Guidance and Counselling, Delta State University, P.M.B. \\ 1, Abraka, Delta State Nigeria. Email: tinaonoyase@gmail.com
}

Received: October 8, 2019

doi:10.11114/jets.v8i2.4671

\author{
Accepted: December 16, 2019 Online Published: December 30, 2019
}

URL: https://doi.org/10.11114/jets.v8i2.4671

\begin{abstract}
This investigation was directed to find out the causes and consequences of School - Related Gender Based Violence (SRGBV) in Ivo local Government area of Ebonyi State, South East, Nigeria. The researcher formulated two research questions and one hypothesis to guide the investigation. The instrument used to elicit information from the respondents is, "School - Related Gender Based Violence and Consequences among Secondary School Students Questionnaire" (SRGBVACASSSQ). The instrument was made up of 9 items on the causes of School related gender based violence and 11 on the consequences. The instrument had a reliability coefficient of 0.87 , language appropriateness, content and facial validity. The purposive sampling technique was used to select 384 respondents that participated in the research. The researcher and two research assistants retrieved 346 copies of the questionnaire from the respondents. The data from the field work were collated by the researcher, the mean and standard deviation were used to answer the research questions while the t-test was used to test the hypothesis at 0.05 level of significance. The researcher used 2.50 as benchmark to find out if respondents agreed or disagreed with the 20 items in the questionnaire. The research revealed in table one a mean score of 3.04 as an indication that many teachers flog students in schools to demonstrate their power over them (students), a mean of 3.00 in table one shows that when bullies are not frequently punished, they continue to bully others in schools, a mean score of 3.07 in table one revealed that boys beat up girls in the secondary schools to show that men are more powerful than women and a mean score of 3.04 in table one revealed that promise of good grades can make some female students to go into sexual relationship with some male teachers.
\end{abstract}

Keywords: school - related gender based violence, consequences and secondary school students

\section{Introduction}

School - Related Gender - Based Violence (SRGBV) appears to be very prevalent in Nigeria and may have affected many children, their families, as well as the communities to which they reside or belong. UNESCO and UN (2016) defined School - Related Gender Based Violence as acts of threats of sexual, physical or psychological violence happening in or around schools. It is made up of verbal abuse, bullying and sexual abuse. Gender discriminatory practices against the families may have engendered this practice and have made girls vulnerable to all forms of violence from their peers as well as their teachers. Sanusi (2015: 25) opined that SRGBV is referred to as violence inflicted on females in and around, or on their way to or from school due to roles attributed to or expected of them, on the basis of their sex or gendered identify. Sanusi stressed that SRGBV include individual action as well as society's harmful practices that negatively impact females' right to education. Continuing, he stated that, if the perpetration of this action is allowed to stay, it could lead to an unsafe and unwelcome learning environment, capable of adversely affecting girls' educational attainment. United States Agency for International Development (USAID) (2012) has pointed out that many studies have indicated that SRGBV is perpetrated on female students by their male peers, teachers or community members. Other negative effects of SRGBV on pupils could manifest in form of low self - concept, withdrawal, aggression, unwanted pregnancy, unsafe abortion, contacting of infectious diseases (such as gonorrhea and syphilis) and phobia for school.

\section{Review of Related Literature}

\section{Probable Causes of School - Related Gender - Based Violence}

The literature has revealed some probable causes of SRGBV to include: 
1. Show of Power

At the school level, male and female teachers tend to inflict corporal punishment on students as a way of demonstrating that they have power over them. In support of this, UNESCO and UN (2016), stated that at school level, there are indications that male and female teachers are more powerful than students. It is thus a demonstration of the belief that teachers have power over their students. Consequently, many of these students suffer physical violence in schools from their teachers in the guise of discipline. According to the United Nations Regional Information Centre (UNRIC) (2019), over 700 million school - aged children reside in countries where they are not totally protected by law from corporal punishment in schools. Nakpodia (2007: 126) noted that corporal punishment holds considerable potential for child abuse.

\section{Poverty}

Secondary school girls from poor homes are now being used for human trafficking. According to Alika and Hillary (2012), Nigeria serves predominantly as supplier of trafficked young females with about $83 \%$ children victims. Sanusi (2015: 26) also identified poverty as one of the causes of SRGBV. Salami (2000), opined, that in Edo State, Nigeria, sexual exploitation of females is transacted with parents' approval. The business, according to Salami involves a syndicate in Nigeria and North Africa whereby the girls are taken away to engage in commercial sex.

3. Emergence of Religious Fundamentalists:

In April 14, 2014, the Vanguard Newspaper reported that about 207 Government Secondary School students, Chibok, Bornu State, Nigeria were abducted from their school dormitory by Boko Haram. In February 19, 2018, another set of girls including Leah Sharibu were abducted from Science Secondary school Dapchi, Yobe State, Nigeria by Boko Haram. Boko Haram appears to be against western education. Although, the Federal Government has succeeded in negotiating the release of some of the abducted girls, others including Leah Sharibu are still under Boko Haram captivity. Alika, Aihie and Ohamaka (2015: 127) reported that the emergence of religious insurgents in places like Pakistan, then under the authority of the Taliban denied females access to western education.

\section{Illiteracy}

Illiteracy may be regarded as one of the causes of SRGBV. In Nigeria, greater number of the populace are illiterates, who do not know the value of education. Some of these uneducated parents force many of their girls into marriage. In addition to that, some of them engage in female genital mutilation, which is regarded as violence against females. According to World Health Organization (WHO), (2010), female genital mutilation is recognized internationally as a violation of the human rights of girls and women. It reflects deep rooted inequality between the sexes and constitutes an extreme form of discrimination against women. The practice violates a person's right to health, security and physical integrity, the right to be free from torture and cruel inhuman or degrading treatment and the right to life when the procedure results in death.

\section{Teachers' Promise of Good Grades}

USAID (2012) has reported sexual violence against girls in schools, in many African countries including South Africa, Zambia, Sudan and Nigeria. The report identified a series of sexual violence perpetrated by male teachers against female students from primary schools to the universities. Sexual harassment, abusive acts, promise of good grades or threat of failure were also identified to be used by many teachers to achieve sexual relations with students. In some instances, students engaged in sexual relations with male teachers for money. According to Wikipedia, reports from Sierra- Leone indicated that girls who cannot pay for school - related expenses are often coerced into sexual relationship by male teachers. Such students may have yielded as a result of some promises made to them. This practice is on-going because some of the victims may lack the moral courage to report to appropriate school authorities.

\section{Disabilities}

Dovries, Kyegome, Zuurmond, Parkes, child, Walakira and Naker (2014), UNESCO and UN (2016), reported that disadvantaged groups are also victims of SRGBV. It has been stressed that more than 3000 school children from Uganda, out of which 24 percent are girls between 11 - 14 years old, suffering from disabilities were victims of sexual violence. In Nigeria, Vanguard Newspaper November 3, 2018 reported that a 13 year old girl was raped by her family members until she died in Benue State, Nigeria. The paper revealed that late Ochanya Ogbanje was raped three times when she was 5 years old and serially raped by three different men when she was between 15 and 16 years. Ochanya Ogbanje was unable to tell her mother because she (the mother) was a deaf.

\section{Gender Discriminatory Norms}

There is a general belief that men are more powerful than women. The gender superiority of men over women seems to promote violence of boys against girls in the school. This was supported by Sanusi (2015: 25), when he observed that 
females are biologically and physiologically perceived as the weaker sex. With this view in mind, female students readily succumb to all kinds of threats from their classmates of the opposite sex.

\section{Unsecured School Environment}

The school environment is supposed to be a safe place for teachers, non - teaching staff and students physically and psychologically. But if the authority of the school is inefficient, then, bullying may be the order of the day. In this situation, you find a student or a group of students beating, hitting and calling their classmates nicknames. Some students even pose as threat to others. UNESCO and UN (2006), have observed that one of three students between the ages of 13 and 15 worldwide were known to have suffered from bullying.

9. Parents' Non - Challant Attitude

The non challant attitude of some parents may have given rise to raping of minors nowadays; these parents tend to undermine the welfare of their female children, by entrusting these minors to their neighbours, friends and some distant relations they (the parents) claim to "trust" so much. Consequently, some girls of between 5 - 15 years may have already been sexually abused. For instance, Vanguard Newspaper of January 29, 2019 reported that a 44 year old man defiled a girl of 7 years of age, 5 times before he was caught in Sapele, Delta State, Nigeria. Vanguard newspaper added that the man confessed that he has been raping minors for many years before he was apprehended.

\section{Influx of Foreign Culture}

Today, Nigeria had been exposed to the rest of the world in terms of menu, dressing and music. In institutions of learning in Nigeria, girls now wear flashy dresses that expose their breasts, back, thighs and buttocks to attract men. In otherwords, females sexually harass males. From observation, some secondary school students wear very short uniforms to school and this could make their male counterparts to sexually harass them.

\section{Consequences of SRGBV}

Among the literature on the consequences of SRGBV are those of Maimuna (2012), who opined that the victims would be faced with psychological trauma, becoming object of jest or pity, dropping out of school, having unwanted babies and breeding of outlaw criminals. Sanusi (2015), reported that the victims of SRGBV may be exposed to high rates of unwanted pregnancy, abortion, sexually transmitted infectious including HIV/ AIDS, dropping out of school, unable to concentrate in school and impeding girls' ability to pursue educational opportunities. Stop violence Against Women (2010), has stressed that due to neglect, abuse, poverty and isolation, victims often have very little money of their own, and virtually no one to assist them. They lack education or specialized skills that would have been useful in securing employment.

\section{Empirical Studies}

Sanusi (2015: 25), investigated types, causes and consequences of SRGBV among Colleges of Education students in Kano State Nigeria: implications for counselling. The study adopted descriptive survey method. A sample of 400 students were selected from the population of 6,000. Self-constructed instrument known as "School - Related Gender Based Violence" (SRGBV) was used to collect data. Data collected were analyzed using a descriptive statistics and a score of $50 \%$ and above was considered as indication of high rate prevalence and for accepting perceived causes or consequences of SRGBV among the colleges of education students in Kano State.

The perceived causes of SRGBV found in the investigation were absence of school laws protecting women from violence, absence of officers to implement laws on SRGBV, degeneration of societal norms and values, ineffective disciplinary action on perpetrators, women's dressing attitude, exchange for academic favours, poor performance of female students and mixed - gender school. Among the consequences revealed in the research were: feelings of insecurity in the school, victims absented themselves from school, discouragement about enrolment of females into higher education and feeling of shame or guilt by victims. Others were causing of strain on marital relations, discouraging female participation in class, and developing negative self - concept; rejection by friends, rejection by the family and transmission of diseases. The finding also included unwanted pregnancy, unwanted abortion, isolation and depression.

\section{Operational Definition of Terms}

School - Related Gender Based Violence: This refers to all actions taken against students either in the secondary school or its immediate environment that impede on their health e.g. sexual violence, flogging and bullying.

Consequences: In this research, consequences means negative effects of School - Related Gender Based Violence on students.

$\mathbf{S S}_{1}$ : refers to students who are in their first year of senior secondary school in Nigeria. 
$\mathbf{S S}_{2}$ : refers to students who are in their second year of senior secondary school in Nigeria.

\section{Statement of the Problem}

Today, the issue of School - Related Gender - Based Violence (SRGBV) seems to be on the increase in institutions of learning, from primary school to the university. There is hardly any day that passes by without one, reading through newspapers; headlines about cases of rape, sexual harassment, abortion, kidnapping or forced marriages. The electronic media is also replete with stories of school - related gender - based violence, which range from bullying to gang raping of female students. Efforts by school authorities and the Government appear not to have yielded the desired result and some of the victims may have dropped out of school because of the humiliation experienced.

What then are the causes of SRGBV and its consequences on secondary school students in Ivo Local Government Area of Ebonyi State, South - East Nigeria? Specifically, the researcher raised the following research questions to guide the study:

1. What are the causes of school - related gender based violence among secondary school students in Ivo Local Government Area of Ebonyi State?

2. What are the consequences of school related - gender based violence on secondary school students in Ivo Local Government Area of Ebonyi State?

\section{Hypothesis}

The hypothesis below was formulated to guide the study:

1. There is no significant difference among students in their assessment of the consequences of school related - gender based violence based on class.

\section{Research Method and Procedure}

The survey technique was used for the research. According to Asika (2002:12) survey research focuses on the population or the universe; data are collected from the population for intensive study and analysis. More often than not, the researcher finds that he cannot possibly study all the subjects or items in the population. Hence, the survey researcher selects a sample from or a subset of the population using some techniques of sampling. The instrument used by the investigator to elicit responses from the students is tagged, "School Related Gender Based Violence And Consequences Among Secondary School Students Questionnaire" (SRGBVACASSSQ). The instrument consisted of 20 items, 9 on the causes of school related gender based violence and 11 on consequences of school related gender based violence. The respondents were to indicate whether they agreed or disagreed with each item on the questionnaire by ticking $(\sqrt{ })$ strongly agreed $(\mathrm{SA})=4$, agreed $(\mathrm{A})=3$, disagreed $(\mathrm{D})=2$ and strongly disagreed $(\mathrm{SD})=1$.

The population of the investigation consisted of all the Senior Secondary School Students of Ivo Local Government Area, Ebonyi State, South East, Nigeria. The purposive sampling technique was used to select 384 students that took part in the research. The investigator and 2 research assistants administered 384 copies of the instrument on the respondents and 346 of them were retrieved showing $90 \%$ return rate. The data collected from the field were scored and collated by the researcher and then used the mean and standard deviation to answer the research questions and $t-$ test, to test the hypothesis. The investigator used 2.50 as benchmark to ascertain if respondents agreed or disagreed with the 20 items in the questionnaire. The researcher tested the hypothesis at 0.05 level of significance. 


\section{Findings}

Research question one: what are the causes of school - related gender based violence?

Table 1. Mean score and standard deviation analysis on causes of school - related gender based violence

\begin{tabular}{|c|c|c|c|c|}
\hline $\mathrm{S} / \mathrm{N}$ & Causes of school- related gender based violence & Mean & $\begin{array}{l}\text { Standard } \\
\text { deviation }\end{array}$ & Decision \\
\hline 1 & $\begin{array}{l}\text { Many teachers flog students in school to demonstrate their } \\
\text { power over them }\end{array}$ & 3.04 & 0.80 & Agreed \\
\hline 2 & $\begin{array}{l}\text { When bullies are not frequently punished, they continue to } \\
\text { bully others in schools }\end{array}$ & 3.00 & 0.79 & Agreed \\
\hline 3 & $\begin{array}{l}\text { The belief that men are more powerful than woman make boys } \\
\text { to beat up girls in secondary schools }\end{array}$ & 3.07 & 0.81 & Agreed \\
\hline 4 & $\begin{array}{l}\text { When the school environment is not very secured, some } \\
\text { students take advantage of that to bully other students }\end{array}$ & 3.02 & 0.83 & Agreed \\
\hline 5 & $\begin{array}{l}\text { Due to illiteracy, some parents have taken their daughters from } \\
\text { school and forced them into marriage }\end{array}$ & 3.02 & 0.81 & Agreed \\
\hline 6 & $\begin{array}{l}\text { Promise of good grades can make some female students to go } \\
\text { into sexual relationship with some male teachers. }\end{array}$ & 3.04 & 0.79 & Agreed \\
\hline 7 & $\begin{array}{l}\text { Promise of money make some female students, (especially } \\
\text { those from poor homes) to engage in sexual relationship with } \\
\text { some male teachers }\end{array}$ & 2.03 & 0.81 & Disagreed \\
\hline 8 & $\begin{array}{l}\text { Wearing of short uniforms by female students to school could } \\
\text { make male students to sexually harass them }\end{array}$ & 2.02 & 0.81 & Disagreed \\
\hline \multirow[t]{2}{*}{9} & $\begin{array}{l}\text { Disabilities such as inability to communicate could make it } \\
\text { possible for some girls to be raped regularly in secondary } \\
\text { schools }\end{array}$ & 3.04 & 0.81 & Agreed \\
\hline & Grand mean & 2.81 & 0.66 & Agreed \\
\hline
\end{tabular}

One of the findings in table one revealed that many teachers flog students in schools to demonstrate their power over them. This is because the mean score of 3.04 is higher than the benchmark of 2.50. Another finding is that when bullies are not frequently punished, they continue to bully others in schools. This is because the benchmark of 2.50 is lower than the mean score of 3.00. The researcher equally found out that the belief that men are more powerful than women make boys to beat up girls in secondary schools. This is illustrated with the mean score of 3.07 which is higher than the benchmark of 2.50. The research revealed that when the school environment is not very secured, some students take advantage of that to bully other students; this is because the bench mark of 2.50 is lower than the mean score of 3.02. The research revealed that due to illiteracy, some parents have taken their daughters from schools and forced them into marriage. The benchmark of 2.50 which is lower than the mean score of 3.02 clearly illustrates this. The research found out that promise of good grades can make some female students to go into sexual relationship with some male teachers; the mean score of 3.04 is more than the benchmark of 2.50. The investigation revealed that the promise of money does not make some female students, (especially those from poor homes) to engage in sexual relationship with some male teachers. This is because the means score of 2.03 is lower than the benchmark of 2.50 . The research revealed that wearing of short uniforms by female students to school does not make male students to sexually harass them; this is because the mean score of 2.02 is lower than the benchmark of 2.50 . The investigation revealed that disabilities such as inability to communicate could make it possible for some girls to be raped regularly in secondary schools. This is clearly depicted by the mean score of 3.04 that is higher than the benchmark of 2.50 . 
Research Question Two: What are the consequences of school - related gender based violence?

Table 2. Mean score and standard deviation analysis on consequences of school - related gender based violence

\begin{tabular}{l|l|l|l|l}
\hline S/N & Causes of school- related gender based violence & Mean & $\begin{array}{l}\text { Standard } \\
\text { deviation }\end{array}$ & Decision \\
\hline 1 & Victims may find it difficult to concentrate in class & 3.07 & 0.80 & Agreed \\
\hline 2 & $\begin{array}{l}\text { Students who are always bullied may develop fear about } \\
\text { school and become irregular in school }\end{array}$ & 2.92 & 0.83 & Agreed \\
\hline 3 & Victims may eventually drop out of school & & & Agreed \\
\hline 4 & $\begin{array}{l}\text { Physical health of students may be affected through } \\
\text { sustaining of injuries from flogging }\end{array}$ & 3.05 & 0.82 & Agreed \\
\hline 5 & Sexual violence could lead to unwanted pregnancy & 3.06 & 0.81 & Agreed \\
\hline 6 & Victims of sexual violence (rape) may contact HIV/ AIDS & 2.96 & 0.83 & Disagreed \\
\hline 7 & $\begin{array}{l}\text { Some students may become disabled due to corporal } \\
\text { punishment (flogging) }\end{array}$ & 2.04 & 0.81 & Agreed \\
\hline 8 & Victims may be unusually sad & 2.91 & 0.79 & Agreed \\
\hline 9 & Victims may become aggressive & 2.95 & 0.81 & Agreed \\
\hline 10 & $\begin{array}{l}\text { Victims may isolate themselves from other students in the } \\
\text { school. }\end{array}$ & 2.96 & 0.83 & Disagreed \\
\hline 11 & Academic performance of victims may become very poor & 2.01 & 0.83 & Agreed \\
\hline
\end{tabular}

The research has revealed in table two that victims of school - related gender based violence may find it difficult to concentrate in class. This is because the mean score of 3.07 is greater than the benchmark of 2.50. The investigation indicated that students who are always bullied may develop fear about school and become irregular schools. The mean score of 2.92 which is higher than the benchmark of 2.50 has clearly shown this. Another finding of the research is that victims of SRGBV may eventually drop out of school. This is because the benchmark of 2.50 is lower than the mean score of 3.00. Yet another finding of the investigation revealed that physical health of students may be affected through sustaining of injuries from flogging. This is because the mean score of 3.05 is higher than the benchmark of 2.50 . The researcher equally found out that sexual violence could lead to unwanted pregnancy as the mean score of 3.06 is greater than the benchmark of 2.50. The investigation also revealed that victims of sexual violence (rape) may contact HIV/ AIDS. This is evidence from the benchmark of 2.50 which is lower than the mean score of 2.96 .

The research revealed that some students may not become disabled due to corporal punishment (flogging). This is because mean score of 2.04 is lower than the benchmark of 2.50. Another finding of the investigation is that victims may be unusually sad. This is portrayed from the mean score of 2.91 that is greater than the benchmark of 2.50 . The investigation has revealed that victims of SRGBV may become aggressive. This is because the benchmark of 2.50 is lower than the mean score of 2.95. The research equally revealed that victims may isolate themselves from other students in the school, as the mean score of 2.96 is higher than the benchmark of 2.50 . The investigator found out that the academic performance of victims may not become very poor; this is because the mean score of 2.01 is lower than the benchmark of 2.50 .

\section{Hypothesis}

There is no significant difference among students in their assessment of the consequences of school-related gender based violence based on class. 
Table 3. T-test on the Difference among Students in their Assessment of the Consequences of School-Related Gender Based Violence Based on Class

\begin{tabular}{l|c|c|c|c|c|c|c|c}
\hline \multicolumn{1}{c|}{ Variables } & $\mathbf{N}$ & $\mathbf{X}$ & SD & Df & t-cal & t-crit & $\begin{array}{c}\text { Level of } \\
\text { Sign. }\end{array}$ & Decision \\
\hline $\mathrm{SS}_{1}$ students & 176 & 32.82 & 2.63 & 344 & -7.34 & -906 & 0.05 & $\begin{array}{c}\text { Not } \\
\text { significant }\end{array}$ \\
\hline $\mathrm{SS}_{2}$ students & 170 & 33.03 & 2.72 & & & \\
\hline
\end{tabular}

The result on table 3 shows that $t$-calculated value of -.734 was less than t-critical value of .906 with 344 degree of freedom at 0.05 level of significance. This implies that there is no significant difference among students in their assessment of the consequences of school-related gender based violence based on class, thus, the hypothesis which says that there is no significant difference among students in their assessment of the consequences of school-related gender based violence based on class is retained.

\section{Discussion}

One of the findings of this investigation is that, teachers flog students in the school to demonstrate their power over them. This lays credence to UNESCO and UN (2016) when they stated that at school level it shows that male and female teachers are more powerful than students hence, they male and female teachers inflict corporal punishment on the students.

Another finding of this research showed that promise of good grades can make some female students to go into sexual relationship with some male teachers. This finding corroborates that of USAID (2012) which reported sexual violence against girls in many African countries including South Africa, Zambia, Sudan and Nigeria. The report identified a series of sexual violence perpetrated by male teachers against female students from primary schools to the universities. Sexual harassment, abusive acts, promise of good grades or threat of failure were used by many teachers to achieve sexual relations with female students.

The investigation has revealed that promise of money make some female students (especially those from poor homes) to engage in sexual relationship with some male teachers. This finding gives support to that of Sanusi (2015), who identified poverty as one of the causes of SRGBV. The finding equally agrees with Salami (2000), who stated that in Edo State, Nigeria, exploitation of females is transacted with parents' approval. Salami stated that the business involves a syndicate in Nigeria and North Africa whereby the girls are taken to Italy and Libya to engage in commercial sex

The research has indicated that disabilities such as inability to communicate could make it possible for some girls to be raped regularly in secondary schools. This finding agrees with UNESCO and UN (2016), when they reported that disadvantaged groups are also victims of SRGBV. The report by UNESCO and UN revealed that more than 3,000 school children from Uganda, out of which 24\% are girls between 11-14 years old, suffering from disabilities were victims of sexual violence. The finding equally lays credence to Vanguard Newspaper in Nigeria, November 3, 2018, that reported of a 13 year old girl that was raped by her family member until she died in Benue State. The research revealed that when the school environment is not very secured, physically and psychologically, some students take advantage of that to bully other students. This finding gives support to UNESCO and UN (2006) that observed that one of three students between the age of 13 and 15 worldwide were known to have suffered from bullying. The researcher found out that sexual violence could lead to unwanted pregnancy. This was corroborated by Madmuna (2012), who opined that the victims of sexual violence would be faced with psychological trauma, becoming object of jest or pity, dropping out of school, having unwanted babies and breeding of outlaw criminals. This finding also agrees with Sanusi (2015), who reported that the victims of SRGBV may be exposed to high rates of unwanted pregnancy, abortion and sexually transmitted infectious including HIV/ AIDS.

The investigation indicated that students who are always bullied may develop fear about school and become irregular in school. This finding lays credence to that of Sanusi (2015), who found out that one of the consequences of SRGBV is the feeling of insecurity in the school by victims and victims absented themselves from school. The research revealed that victims may isolate themselves from other students in the school. This finding corroborates that of Stop violence Against Women (2010) that stressed that, due to neglect, abuse, poverty and isolation, victims often have very little money of their own, and virtually no one to assist them.

\section{Conclusion}

The conclusion that may be drawn as a result of the findings is that school - related gender based violence exists in secondary schools of Ivo local government area of Ebonyi State, South East, Nigeria. Some of the causes of SRGBV include, flogging of students by teachers, bullies not frequently punished, boys beating up girls in the school and unsecured school environment that gives rise to some students to bully others. The SRGBV may have led to unwanted 
pregnancy, bullied students becoming irregular in school and contacting of sexually transmitted infectious disease like HIV/ AIDS by some victims.

\section{Recommendations}

Based on the findings and conclusion reached, the following recommendations are made by the researcher:

1. The Federal Government should enforce the law against corporal punishment in all secondary schools in Nigeria and teachers who do otherwise should be disciplined

2. School authorities should stipulate punishment to be meted out to students who bully their classmates so as to serve as deterrent to potential bullies.

3. Male teachers should be thoroughly supervised by their Department Heads or Vice - Principals to ensure that they (male tutors) desist from using marks to lure students into sexual relationship.

4. Principals of secondary schools should ensure that students and teachers alike, adhere to school rules, regulations so that students will feel secured in the school environment.

5. The Federal Government of Nigeria should adopt new strategies and acquire more sophisticated equipment in order to curb Boko Haram insurgency and abduction of female students from schools in Nigeria.

\section{Counselling Implications}

The following are the implications of the study:

- Counsellors in secondary schools are to organize parents' conferences for uneducated parents in order to counsel them on the value of education and the consequences of forcing their daughters into early marriage.

- Secondary school counsellors are to organize group counselling for bullies so as to make them understand the effects of their actions on their fellow students and also teach them skills of interpersonal relationship.

- Tutors in secondary schools who flog students to demonstrate their power over them should be counselled to refrain from such negative practice and rather act as parents to the students.

\section{References}

Alika, H. J., \& Hillary, J. C. (2012). Human trafficking in Nigeria, Journal of Educational Research and Development. 793, 28-35.

Asika, N. (2002). Research methodology behavioural sciences, Abuja: Longman Nigeria Plc.

Dovries, K., Kyegome, N., Zurrmond, M., Parkes, J., Child, J., Walakira, E., \& Naker, D. (2014). Violence against primary school children with disabilities in Uganda: B. M. C. Public Health, 14(1). https://doi.org/10.1186/1471-2458-14-1017

Nakpodia, E. D. (2007). Education Law, Warri: Jonokase, Nig. Co.

Onoyase, D. (2013). Causes and consequences of sexual abuse among school children in Nigeria: Implication for counsellor: Book of reading, An official publication of CASSON, Kano Chapter.

Salami, I. I. (2000). The girl - child work and health hazards. Journal of Women in Academics, 6(1), 122-134.

Sanusi, M. K. (2015). Types, causes and consequences of school - related gender based violence among college of education students in Kano State: Implications for counseling, Ed. Adegoke, A, Aluede, O. and Eweniyi G. in Counselling Association of Nigeria (CASSON).

Stop Violence Against Women (2010). Retrieved August 8, (2014). http://www.stopraw.org/domesticviolence and housing. Html.

UNESCO and UN (2016), Global guidance on addressing school-related gender based violence. http://unesdoc.unesco.org/ timages/ 0024/ 002466/ 24665/ E.pdf

UNICEF (2007). Violence against women.www-unfdg.org/ gender violence. Htm retrieved June, 8, 2014.

United Nations Regional Information Centre (UNRIC) (2019). Putting a stop to school-related gender-based violence. https://ec.europa.eu/europeaid/news_and_events/putting_stop_school_related_gender_based_violence

United States for International Development USAID (2012). Unsafe school: A literature review of school-related gender based violence in developing countries; Retrieved, June 17, 2014 from http://www.wc.wnlineorg/images/reviewpdf

Vanguard Newspaper, April 14, (2019). Why Leah Sharibu release is difficult. 
Vanguard Newspaper, November 3, (2018). My mother was deaf, so I could not tell her.

Wikipedia, the free encyclopedia "School-related gender-based-violence" Retrieved $14^{\text {th }}$ February from https://en.wikipedia.org/wiki/school_related_gender_based_violence

World Health Organization (2011), http:daofthegirl.org/2011 Human Rights-Horror/ Read One girl's opinion

\section{Copyrights}

Copyright for this article is retained by the author(s), with first publication rights granted to the journal.

This is an open-access article distributed under the terms and conditions of the Creative Commons Attribution license which permits unrestricted use, distribution, and reproduction in any medium, provided the original work is properly cited. 